\title{
ニュージーランド森林資源価値の最大活用*
}

\section{Maximising the Value of New Zealand's Fibre Resource} Terry J. Fullerton, Gerard P. Horgan and R. Paul Kibblewhite
New Zealand Forest Rasearch Institute, New Zealand

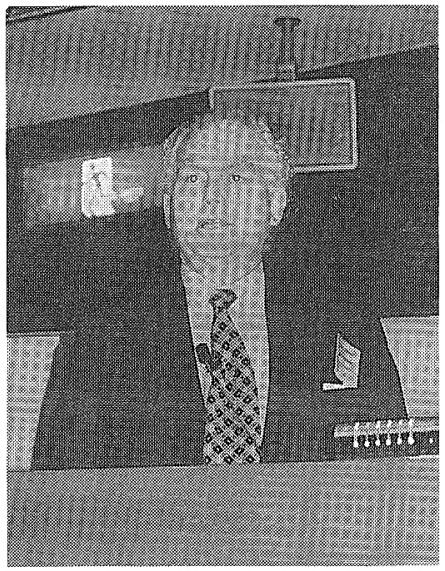

Terry J. Fullerton

The forest industry in New Zealand continues to expand and it is forecast that the amount of forests available to harvest will increase substantially over next 30 years. Based on the forests already planted there will be an availavility of at least 30 million $\mathrm{m}^{3}$ of wood per annum by the year 2010. Depending on planting rates over the next 20 years the harvest could well increase to more than 50 million $\mathrm{m}^{3}$ from 2025 onwards. To achieve this level of harvest will require a planted forest estate in excess of 2.5 million hectares. By far the most predominant species is radiata pine which grows exceptionally well under New Zealand conditions. With forestry already accounting for $12.8 \%$ of New Zealand's total exports this additional wood supply represents a major opportunity for New Zealand to substantially increase its export earnings by maximising the value of this wood and fibre resource.

Radiate pine is well suited to the manufacture of a wide range of solid wood, reconstituted wood products and pulp and paper products. Its value can also be significantly enhanced by taking advantage of the variability in wood and fibre types both within a single tree and between families and clones of the same species. This variation can be used to maximise product quality by selecting different parts of the tree or differrent radiata pine clones for a particular end use.

(quoted from the original paper)

\section{1. 序説}

ニュージーランドの森林産業は成長を持続しており， 伐採可能な材積は向こう 30 年間増加を持続すると見 られる。文でに植林ずみの森林状況から見て 2010 年 までは年間伐採量は少なくとも 3,000 万 $\mathrm{m}^{3}$ は確保で きる見通しである。今後 20 年閒の植林率から計算し

\footnotetext{
*(翻訳) 大昭和製紙株式会社中央研究所 久保田道孝
}

ていくと 2025 年以降には年間伐採量は 5,000 万 $\mathrm{m}^{3}$ 以上にのぼるものと見られる。この伐採水準を達成す るには250万 ha 以上の植林面積が必要になる。主力 樹種となるのはラジアータパインで，この木はニュー ジーランドの環境に特に適合している。すでにニュー ジーランド全輸出量の $12.8 \%$ に達している林産物に 加えて，この新規な植林資源の有効活用が国家の所得 に大きく貢献していくと期待できる。

ラジアータパインは工業的には広い用途があり, 製 
材製品，パーテイクルボード類，パルプ，製紙の原料 に適している。ラジアータパインはまた，木材や纎維 としての多様性も注目すべき特长である。间一樹種の 中でも個体毎や闹族，さらには闹一クローンの間でも 多様性を持っている。

特定の最終用途に対し, 樹体のどの部分を使うか, あるいはラジアータパインのどの種類を選ぶかによっ て製品の品質要求に幅広く対応できる。

\section{2. 資 源}

\section{1 森林の現状}

図1に示すグラフはこれまでのニュージーランドの 森林経営の歴史で明確な植林ブームが三度起きたこと をホしている。

最初の植林は国内自給能力の確保のため天然林から の木材供給の代替策として実施された。次の植林は 1960 年から盛んになり林産品輸出産業振興策の基盤 となった。この第二次の植林ブームはほぼ 20 年間続 いた。このブームは 1980 年代の後半に税制の変吏と 政府のリストラと国の資産売却の影響を受けて終㫮に 们かった。

最近の植林ブームは長期投資の対象としてニュージ
ーランドでの森林に対する関心の盛りトがりによりス 夕ートし，ほとんどの植林は多数の小規模投資家が行 っている。これが第三次の植林ブームとなり年間 7 lj ha を越える新規の植林が続いている（表 1)。

\section{2 今後の針葉樹材の供給}

現在のラジアータパインの植林地は幼木が多く，全 体の $2 / 3$ が 15 年未満のものである。最適伐期は 26 年 から 28 年の間で，通常はha当たり 550 から $600 \mathrm{~m}^{3}$ の收量が期待できる。現在の伐採量は年間 1,700 ) $\mathrm{m}^{3}$ で, 抄およそこの $1 / 3$ は国内での利用になっている。 残り 2/3（96 年 12 月時点の計算で $1,100 ~ j \mathrm{~m}^{3}$ ) は丸 太 $\left(560\right.$ 万 $\left.\mathrm{m}^{3}\right)$ や加工品として輸出される。伙にこ れ以上の植林面積の拡大がなくても既存の人に林の成 長により今後 5 年目から 10 年目の間には伐採聶が作。 間約 3,200万 $\mathrm{m}^{3}$ に達する見通しである。世:界的に見 てもすでに高い水準に達している国内の消費昂はこ机 以上:は增加しないものと見られ，このため輸出余力は 作間 2,600 今 m $\mathrm{m}^{3}$ ，すなうち現在の輸出量の 2 倍のレ ベルまで增加するものと期待できる。

現在の森林資源の了測をもとにすると，21 世糺の 最初の 25 年間では針葉樹の植林面積は現状の 2 倍に 達する見通しであり，また林業の生産規模は年間

\section{NEW FOREST AREA PLANTED SINCE 1921}

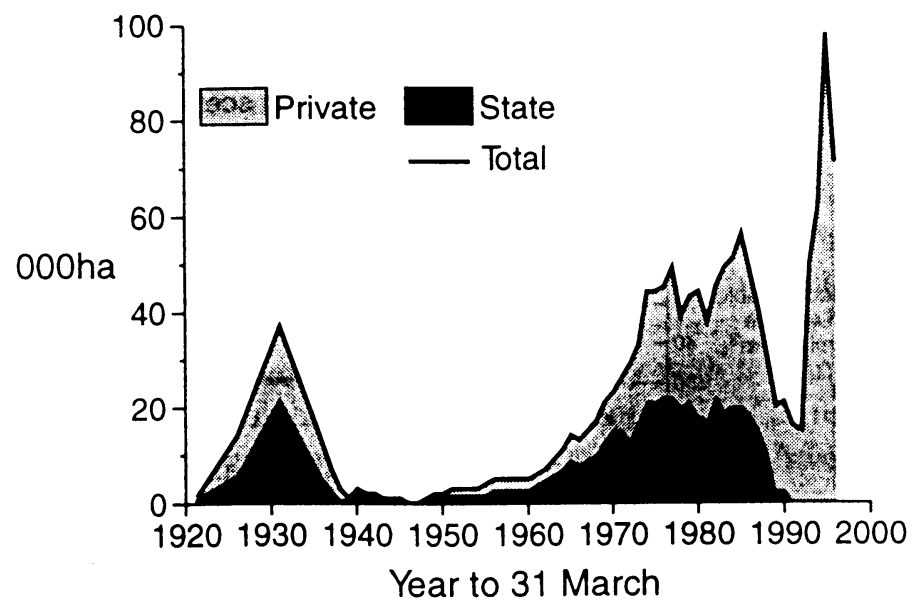

Source: MOF, Statistics Section

Fig.1 The increase in plantation forest area in New Zealand since 1921.

Table 1 Planting area of new forests in New Zealand since 1991

\begin{tabular}{c|c|c|c|c|c|c}
\hline Year & 1991 & 1992 & 1993 & 1994 & 1995 & 1996 \\
\hline New Plantings (000 ha) & 15 & 50 & 62 & 98 & 71 & 82 \\
\hline
\end{tabular}




\section{PROJECTED FUTURE HARVEST \\ Based on various new planting scenarios}

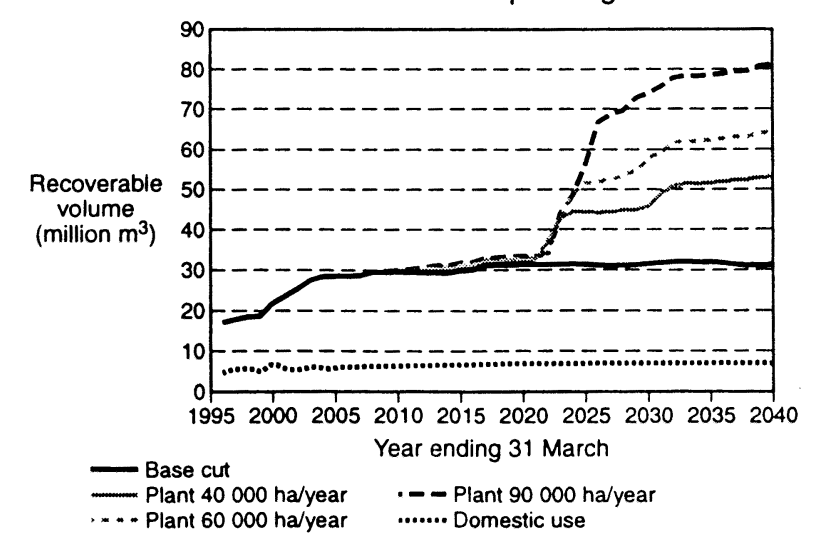

Fig.2 The effect of planting rates on the future wood harvests.

Source NEFD, 1996.

5,000 J $\mathrm{m}^{3}$ に達し，フィンランド，フランス，ドイ ツ（†として針葉樹）マレーシア，インドネシア (広 葉樹）の諸国を卡回わり，現在のスエーデンに迫る規 模になる (図 2)。輸出も現状の生産量の $65 \%$ に対し 90\%まで達し, この結果, ニュージーランドは太平洋 地域でも指折りの木材輸出国となっていくだろう。

\section{3 森林の状況}

他の針葉樹やユーカリの植林は特にこの 2,3 年増 加している一方で，ユーカリ材とダグラスファー材の 牛産は依然として全生産量の各 $3 \%$ オ゙つにととまって いる。

㭻林面積の $94 \%$ を回る部分がラジアータパイン で，表 2 に亦すように樹種別の人工林面積では $90 \%$ を越えている。

\section{4 パルプ用材と古紙の活用}

紙パルプ分野の将来展望からは薄物化に伴う生産量 の減少と, 製材巨場からのチップ供給量のわずかな増 加が 5 年後から 10 年後の期間で予想される。伐採量
増加による供給の増加はほぼコンスタントに続く見込 みである。パルプ材の供給不足の可能性は残るのでこ れを回避するためパルプ材としての効率的な成長を求 めてユーカリが植林されることになった。

歴史的にもニュージーランドでは古紙の利用は盛ん ではなかったが，最近になって新しく 10 万トンの十 紙をライナーボード生産に向ける計画が発表され，そ れ以外にもすでに 14 万トンの古紙がライナーの生産 に向けられている。

\section{5 森林の所有形態}

四 1 に示すようにニュージーランド政府は伝続的に 森林の主要部分を国有としていたが，現在は方針を替 えて政府は新規の植林事業には関与しなななった。

ニュージーランドでの森林保有の大手企業では Fletcher Challenge (28 万 8,000 ha 所有) と Carter Holt Harvey (32 万 5,000 ha 所有) の 2 社が知られ ている。

Fletcher Challenge 社所有の森林の一部は国際的

Table 2 Planted Production Forest Area By Species (as a April 1996)

\begin{tabular}{l|c|c}
\hline \multicolumn{1}{c|}{ Species } & Hectares $(000)$ & Percentage ot Total \\
\hline Radiata pine & 1,396 & 90.5 \\
Douglas fir & 70 & 4.5 \\
Other exotic softwoods & 33 & 2.2 \\
All exotic hardwoods & 43 & 2.8 \\
\hline \multicolumn{1}{c|}{ TOTAL } & 1,542 & 100.0 \\
\hline
\end{tabular}

Source : NEFD, 1996. 
な資本関係により Citifor 社: (China International Trust \& Investment Corporationの子会社) と Brierley Investments 社が所有しており，一J Carter Holt Harvey 社はInternational Paper 社の 要株主となっている。

\section{3. 品質向上}

ニュージーランド木材資源の品質向トのためには

1。木材とチップの密度と繊維辰による選別

2. 品種改艮

3. 繊維の分離

\section{1 木材とチップの選別}

北欧のスプルースのような種と比較するとラジアー タパインは纎維長, 断面の小法, 木Hの粗さに幅広い 多梯性が見られる (Kibblewhite 1989, Cown 1992， Kibblewhite and Bawden 1992)。ラジエーターパ インの特長となる単一樹体中に見られる樹龄の変遷に よる木材と構成繊維の物性の多様性が垃年にわたって ニュージーランドの木材産業に恩恵をもたらしてきた。

図 3 に亦寸ように幹は纎維の形態により 3 種類のグ レードに分類することができる。そしてこの相異なっ た品質特性により別々の分野に材木として供給できる。 寸なわち, 傷のない仕上げ材用途の節なし材, 輸出や

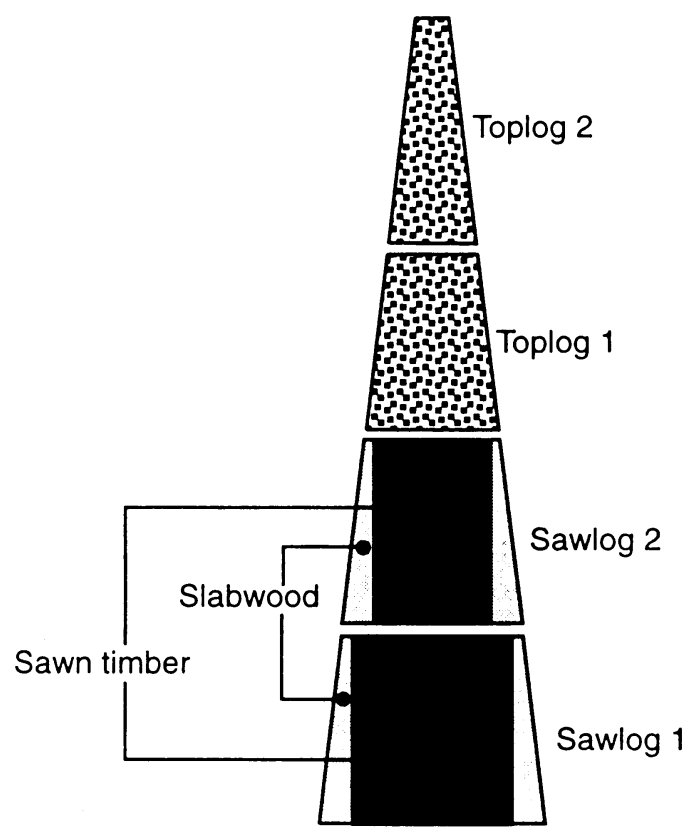

\section{Schematic diagram of tree components}

Fig.3 Schematic of tree showing the source of slabwood.
構造材や工業向けの節のある材, パルプやパーテイク ルボード向けの，一次製材からの残材で付加価值の低 い材の 3 種類に分類できる。パルプ用材向けにも, 蓝 望があればこのような品質別に木材を分別して供給す ることができる (Kibblewhite 1992)。

牛育場所, 森林の形態, 伐採時の樹齢などの諸条件 は木材，木材繊維，パルプ品質などに対してかなりの 影響を与えている。ラジアータパインのこのような多 様性がニュージーランドでの資源の評価につながり, 何種類もの多彩な種類の市販パルプもこのことを基本 に開発されてきた。様々な製品の品質要求に忍じてこ の多彩な品質のパルプを使い分けることができる。パ ルプ品質に特長を持たせることがラジアターパインの 叮能性を最大限に引き出し, パルプ品質の安定と, 品 筫特性を最大限に発揮しながら最終製品からの要求に 㐫えることができる。

チップの密度を低い, 中間, 高いものと使い分ける ことによりパルプ繊維の品質を変えることができる。 評価パラメーターとなるチップ密度は, チップが樹体 のどの部分から採取されるか, 伐採時の樹龄がどれく らいか, どの場所で生有したきたかなどの要素で決ま つてくる。従って, チップと最終的なパルプの品覧は, そのチップが成熟木の製材残材の Top Logsからか Slabwood からか, 年代が入り交じる場合の樹体全体 からのものなのかによって左右される(网 3)。Top Logs や樹体全体からのチップは 14 年から 20 年まで の若い年輪で構成されていて比較的低い密度になる。 Sawlogsの外側に当たるSlabwood は Sawlogsの作: 輪の数により中間から高必密度になる。チップの密 度はハンドシートの引き裂き, 破裂, 引つ张りの哜強 度に関係する。

\section{2 品種改良}

現在植林済みのラジアータパインの大部分は成上が 速く, 樹形が優れるように選別された改良品種を使つ ている。今研究が進められているのは最終用途にさら に適合する品質に向けたラジアータパインの同族やク ローンの特定による品種改良である。この研究の中で 成熟した長繊維を若木のうちに形成する品種や, 図4 (Kibblewhite and Shelbourne 1997) にホすような 密度と体積の向、を:をもたらすような品種の選別を進め ている。

最近の研究成果によれば，クラフトパルプ纎維や八 ンドシートの物性から見てチップの密度は闬一地域内 で成长したラジアータパインでは 25 年から 13 年の間 に極大となることを亦している。(Kibblewhite and Shelbourne 1997) 

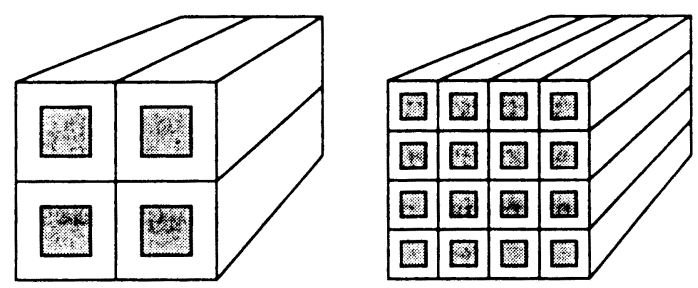

\section{Volume I = Volume II \\ Density 1 = Density $\|$ Fibres 1 Fibres 11}

Fig.4 Schematic diagram of wood of the same density with fibre numbers and dimensions.

以トに示卞最終用途への適合性は 25 年生の樹体で クラフト繊維の性質として示された。

・小さな断面積で厚い細胞壁の $\mathrm{P}$ ， radiataの長く て紼めの繊維は破壞されにくく, 高いバルクの紙 などの特垃ある製品を作るのに適している。この ような纎維は丈夫で時には叫解しにくいことがあ る。繊維が長いことはこのパルプの用途について は望ましく，同㥞にできるだけ短伐期で長い繊維 を確保するため植林の伐採時期を検討する上:で重 視さ机る。

・小さな断面積で溥い細胞壁のP． radiataのすこ

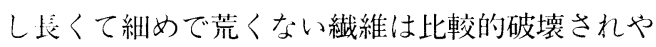
すく川解もされやすいが，上質の印刷用紙や筆記 用紙をつくる場合，かさ高でつなぎパルプとして として優れた特性がある。ハンドシートのかさ高 さを維持するため，最小でも $2.1 \mathrm{~mm}$ ほどの纎維 垓が P. radiataにつなぎパルプとして必要であ る。嬉繊維の割合が多くなると紙の地合が悪くな るので繊維垓にも上限がある。

・きめ緇かく薄い細胞壁のP. radiataの短繊維は

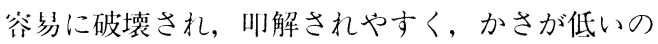
でテイッシュに配合するなど密度の高い製品に 效果を発揮する。

\section{3 ファイバーフラクショネイション}

パルプの品質を向上させる 3 番目の検討は，パルプ 化した繊維を長くて大きな繊維と短くて細かい繊維に 分離する力法についてである。木材中に見られるいろ いろな繊維を分離するため, 化学パルプと機械パルプ の両方についてスクリーンとクリーナーを使ったテス トでの研究成果が得られている。

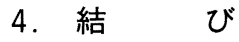

来世紀の初頭には植林の成果によりアジア太平洋地 域において木材諸製品の代表的な輸出国となる見通し である。ニュージーランドの森林産業は木材の主要供 給者となり，この針葉樹資源をもとにした製品が顧客 の幅広いニーズに対応していく中で資源価值の最大限 の活用が達成できると考えている。

\section{参考文献}

1) Cown, D. J. : New Zealand P. radiata and Douglas fir-Suitability for processing. NZ Ministry of Forestry, FRI Bulletin No. $168,1992$.

2) Kibblewhite, R. P. : New Zealand radiata pine kraft pulp qualities. PAPRO New Zealand Brochure, July 1989.

3) Kibblewhite, R. P. and Bawden, A. D. : Kraft fibre qualities of Pinus radiata toplogs, thinnings, slabwood, and a "genetic misfit”. NZ Journal of Forestry Science 22(1) : 96-110 (1992).

4) Kibblewhite, R. P. and Shelbourne, C. J. A. : Genetic selection of trees with designer fibres for different paper and pulp grades. PAPRO Report B 206. Transactions of the 11th Fundamental Research Symposium "Fundamentals of Papermaking Materials", Cambridge, September 1997.

5) NEFD. 1996 : National and Regional Wood Supply Forecasts 1996. Ministry of Forestry, Wellington. $150 \mathrm{p}$. 